\title{
Immune Status and Growth of Broiler Fed Diet with Microparticle Protein Added with Natural Acidifier
}

\author{
N. Suthama*, B. Sukamto, I. Mangisah, \& L. Krismiyanto \\ Faculty of Animal and Agricultural Sciences, Diponegoro University \\ Semarang 50275 Central Java, Indonesia \\ Corresponding email: nsuthama@gmail.com \\ (Received 29-10-2020; Revised 27-11-2020; Accepted 22-12-2020)
}

\begin{abstract}
The present study was conducted to evaluate the feeding effect of diet composed of microparticle protein added with lime juice as an acidifier on immune status and efficiency of protein utilization in relation to the growth of broiler chicken. Dietary treatments tested were P1 was diet with $20 \%$ intact protein and $\mathrm{CaCO}_{3}$ as a Ca source, P2 was diet with $20 \%$ microparticle protein and eggshell as a Ca source added with $1.2 \%$ lime juice, and P3 was diet with $20 \%$ microparticle protein and eggshell as a Ca source added with $2.4 \%$ lime juice. Variables measured were protein and amino acids digestibility, retentions of $\mathrm{N}$ and Ca, fecal $\mathrm{N}^{\tau}$-methyl histidine $\left(\mathrm{N}^{\tau}-\mathrm{MH}\right)$ excretion as a protein turnover index, lymphoid organs, heterophil and lymphocyte $(\mathrm{H} / \mathrm{L})$ ratio, immunoglobulin $\mathrm{A}(\mathrm{IgA})$ as a body resistance indicator, feed consumption, body weight gain (BWG), and feed conversion ratio (FCR). The experiment was arranged in a completely randomized design with 3 treatments and 8 replications. Data were subjected to analysis of variance and Duncan test at $5 \%$ probability. Protein and amino acid digestibility, $N$, and Ca retentions were significantly $(\mathrm{p}<0.05)$ higher in P2 and P3. However, the $\mathrm{H} / \mathrm{L}$ ratio was significantly $(\mathrm{p}<0.05)$ lower in both treatments compared to P1. Bursa fabricius and lymph weights were not difference, but BWG in P2 significantly $(\mathrm{p}<0.05)$ increased. In conclusion, protein and some essential amino acids digestibility, $\mathrm{N}$ and Ca retentions, IgA, and BWG increase with the decrease in $\mathrm{H} / \mathrm{L}$ ratio, fecal $\mathrm{N}^{\tau}-\mathrm{MH}$, feed consumption, and FCR in broiler fed diet composed of microparticle protein source with additional $1.2 \mathrm{~mL}$ acidifier of lime juice.
\end{abstract}

Keywords: acidifier; broiler chicken; immune status; microparticle protein; protein digestibility

\section{INTRODUCTION}

Protein sources as the main component for poultry feed are usually derived from a combination of fishmeal and soybean meal. Both ingredients are an ideal combination due to their complementary effects for the fulfillment of protein or amino acid requirements. The amount and quality of protein sources are the main limiting factors that determine poultry performance, especially broiler. Protein and Ca supply, for meat and bone growth, respectively, are important nutrients to support broiler productivity. Increasing protein utilization efficiencies can be achieved by maintaining nutrient absorption still in an adequate amount and does not interfere with productivity. Processing protein source ingredients to be in micro size, called microparticle protein, is one method that can be applied to increase the efficiency of protein utilization. The previous study indicated that protein digestibility and $\mathrm{N}$ retention increased in broiler force-fed microparticle protein derived from fishmeal and soybean meal (Suthama \& Wibawa, 2018).

Feeding feed additives in the poultry industry for the purposes of improving productivity has been in- creasingly popular in the last few decades (Dhama et al., 2014; Al-Jaf et al., 2019). Increasing the efficiency of protein utilization in particular and feed utilization in general plays a key role in the broiler industry for economical meat producers. Nowadays, the efficiency of meat production and food safety of poultry products for humans become a main trend of consideration. Antibiotic in the past decade was massively used either for disease control or improving the performances of poultry production. Some investigators previously reported that poultry farmers from small scale to large farm used antibiotic as a growth promoter and also for disease control (Mehdi et al., 2018; Salim et al., 2018). Continuous feeding antibiotics for a long time emphasizes the attention on side effects such as gaining residue in the product, raising a resistance of certain bacteria in the host animal, as well as harmful effects for the consumers. The safety of broiler meat called "clean product" becomes the main highlight due to the use of antibiotic growth promoters. The various natures of antibiotic use in animal feed potentially affect human health (Landers et al., 2012). Therefore, the use of antibiotics in feed and feeding programs for poultry in Indonesia has been banned since 1 January 2018 (Sivaraman \& Parady, 2018), even in the 
European Union, it has been much earlier prohibited, since 1 January 2006 (Castanon, 2007).

At present, dietary supplementation of organic-feed additives with low price and consumer-health friendly has begun to be widely used as an alternative to antibiotic. Source of acidifier naturally available such as lime is easy to obtain and can be simply applied. Lime juice contains citric acid as one component of organic acids improved nutrient utilization, especially protein and Ca (Jamilah et al., 2013), which can also be correlated with the increased villi growth of broiler given synthetic citric acid (Abdelrazek et al., 2016). Feed supplemented with organic-acids feed additive could change $\mathrm{pH}$ and morphology of gastrointestinal tract and had a positive effect on the health and performances of poultry (Yang et al., 2009). Positive interaction between protein and Ca microparticle mediated by acidifier of lime juice will be efficient and effective for the production of the broiler. The change in the intestinal $\mathrm{pH}$ has been reported to increase the total and activity of beneficial bacteria such as lactic acid bacteria (BAL), and in contrast, decreased Escherichia coli growth in broiler given prebiotic inulin (Krismiyanto et al., 2014). The better microbial balance has positive impacts on gastrointestinal health, improves nutrients utilization, and increases productivity. It is well known that $\mathrm{Ca}$ is highly absorbed in an acidic condition and is bound with protein in a binding form called calcium-binding protein ( $\mathrm{CaBP})$. Protein and $\mathrm{Ca}$ are "always together" during the process of absorption, but the relation to the single test of either fishmeal or soybean meal indicated no dramatic change in Ca retention even though the protein digestibility was increased (Suthama \& Wibawa, 2018). It is assumed that this condition can be related to the sub-optimal availability of $\mathrm{Ca}$ in both ingredients. Therefore, continuing research is important and required using a complete feed composed of microparticle protein and sufficient Ca derived from eggshell added with acidifier.

Sources of microparticle protein and organic dietary $\mathrm{Ca}$ can be a basic requirement for formulating renewable poultry feed. The particle size of feed could maximize nutrients utilization, improve growth, and prevent the birds from intestinal diseases due to the effect of pathogenic bacteria (Pan \& Yu, 2014). Some special experiments concerning unprocessed dietary protein (intact protein) have been previously conducted with various additives. There were some dietary supplementations have been conducted in the broiler, such as acidifier of lime juice (Jamilah et al., 2013), apple vinegar and ginger root (Hayajneh, 2019), and a combination of ginger and turmeric extract added with Lactobacillus sp. (Risdianto et al., 2019). However, research concerning a combination of microparticle protein and organic $\mathrm{Ca}$ of eggshell with the addition of lime juice as an acidifier has never been conducted. The size of feed particles exerts various advantages for production in poultry through the development of the gastrointestinal tract that eventually improves nutrients utilization to support better performances (Amerah et al., 2008; Pacheco et al., 2013; Rubio et al., 2020). The reduced particle size is closely related to the intensive accessibility of digestive enzymes to nutrients resulting in the increased feed di- gestibility (Jambrak et al., 2014; Huang \& Stein, 2016). As it has been previously described that the high growth rates of broilers have to be supported by appropriate bone growth that needs adequate Ca supply. Therefore, the present study was conducted to evaluate feed composed of microparticle protein sources and organic Ca derived from eggshell on body resistance and protein deposition in relation to the growth of broiler.

\section{MATERIALS AND METHODS}

The experimental protocol used in the present study was approved by the Institutional Research Project under the supervision and inspection of the Institute of Research and Community Services, Diponegoro University number 101-65/UN7.6.1/ $\mathrm{PP} / 2020$, and was reinforced with the rule of the Republic of Indonesia's law number 41, 2014 concerning animal management and health.

\section{Experimental Animal and Feed}

One hundred and ninety two birds of 14-day old broiler chicken with an average initial body weight of $271 \pm 33 \mathrm{~g}$ were used as experimental animals, and eight birds for endogenous correction. The adaptation period was provided for two weeks, which was divided into 2 steps. The first 6 days was fully given commercial feed, and the rest day (8 days) was fed a combination of commercial and experimental diets. The combination was gradually changed with the ratio of commercial and experimental feed was $75 \%$ and $25 \%, 50 \%$ and $50 \%, 25 \%$, and $75 \%$, and the last $100 \%$ experimental feed. Each ratio was provided within 2 days interval, respectively. The adaptation period was terminated when it reached $100 \%$ experimental diet prior to the feeding trial on day 14. The birds were allocated to 3 treatments group and provided an experimental diet until 6-weeks old. Half of the chickens (72 birds), at the last week of the experiment, were separated and moved to the individual cage (battery) for blood sampling and excreta collection (digestibility trial). Dietary treatments were formulated with the same protein and energy contents of $20 \%$ and $2963 \mathrm{kcal} / \mathrm{kg}$ in average, respectively (Table 1). The birds were given dietary treatments in pelleted form ad libitum and free access to drinking water.

Protein source ingredients, fishmeal and soybean meal, were processed to be microparticle based on the method of ultrasonic bath treatment using ultrasound transducer as was reported elsewhere (Suthama \& Wibawa, 2018). Intact fish meal and soybean meal were ground and then dissolved in distilled water $(1: 4, \mathrm{w} / \mathrm{v})$. Two $\mathrm{mL}$ of virgin coconut oil was added for the respective of $500 \mathrm{~mL}$ solution prior to be run for $60 \mathrm{~min}$ in the ultrasound transducer (Power Sonic 405, Hwashin Technology Co., Korea). Sound wave was transferred from the transducer that can radiate to the liquid at $40 \mathrm{~Hz}$ was the principal work of ultrasonic bath treatment to obtain microparticle.

A natural source of acidifier was prepared by cutting the clean washed lime fruits into two transverse sections. The content of lime fruits was then manually 
squeezed to expel the juice. The liquid squeezed from lime fruits was filtered to remove the possibility of containing seeds or other particles to obtain juice ready to use. Calcium organic was prepared from eggshell in the form of powder with a simple procedure of grinding, and then it was sieved to find a particle size of 60 mesh on average.

\section{Treatments and Variables Measurement}

There were three dietary treatments tested in the present study. First, a diet with $20 \%$ intact protein and $\mathrm{CaCO}_{3}$ as Ca source (P1). Second, a diet with $20 \%$ microparticle protein and eggshell as Ca source added with $1.2 \%$ lime juice (P2). Third, a diet with $20 \%$ microparticle protein and eggshell as Ca source added with $2.4 \%$ lime juice (P3). Lime juice was mixed with a small portion $( \pm 30 \mathrm{~g})$ of experimental feed, and it was served in the morning to ensure the birds can completely consume according to treatment level. Another portion of feed without lime juice was given thereafter to fulfill the daily requirement.

Retentions of dietary Nitrogen (N) and Calcium (Ca) were determined simultaneously together using a combination method of total collection and indicator (Fe2O3) marked feed. Determination of amino acid

Table 1. Composition and nutrition content of experimental feed $^{1)}$

\begin{tabular}{lccc}
\hline \multirow{2}{*}{ Ingredient (\%) } & \multicolumn{3}{c}{ Dietary treatments } \\
\cline { 2 - 4 } & $\mathrm{P} 1$ & $\mathrm{P}^{2)}$ & $\mathrm{P}^{2)}$ \\
\hline Yellow corn & 51.0 & 51.0 & 51.0 \\
Rice bran & 14.6 & 14.5 & 14.5 \\
Intact fishmeal & 9.6 & - & - \\
Microparticle fishmeal & - & 9.6 & 9.6 \\
Intact soybean meal & 24.0 & - & - \\
Microparticle soybean meal & - & 24.0 & 24.0 \\
Egg shell & - & 0.6 & 0.6 \\
CaCO & 0.5 & - & - \\
Premix & 0.3 & 0.3 & 0.3 \\
Total + lime juice (\%) ${ }^{3)}$ & 100 & $100+1.2$ & $100+2.4$ \\
Nutrition content & & & \\
$\quad$ Metabolizable energy ${ }^{4)}$ & & & \\
(kcal/kg) & 2,942 & 2,928 & 2,892 \\
Protein & 20.54 & 20.36 & 20.02 \\
Ether extract & 4.06 & 4.08 & 4.00 \\
Crude fiber & 5.43 & 5.43 & 5.37 \\
Ash & 6.29 & 6.33 & 6.21 \\
Calcium & 1.32 & 1.4 & 1.38 \\
Phosphorus & 0.78 & 0.81 & 0.80 \\
\hline
\end{tabular}

Note: $\mathrm{P} 1=$ Feed composed of intact fish meal and soybean meal without Ca of egg shell; $\mathrm{P} 2=$ Feed composed of microparticle protein of fish meal and soybean meal, and Ca of egg shell $+1.2 \%$ acidifier of lime juice; P3= Feed composed of microparticle protein of fish meal and soybean meal, and Ca of egg shell $+2.4 \%$ acidifier of lime juice.

${ }^{1)}$ Determined value at the Laboratory of Animal Nutrition and Feed Science Faculty of Animal and Agricultural Sciences, Diponegoro University; ${ }^{2}$ Nutrients content was adjusted to be $100 \%$ unit; ${ }^{3)} 1 \%$ was equal to $1 \mathrm{~mL}$ lime juice per $100 \mathrm{~g}$ feed; ${ }^{4}$ Calculated value based on the formula of Sibbald \& Wolynetz (1985). digestibility was specifically performed according to the method of Ravindran et al. (1999). Immune status based on blood concentrations of immunoglobulin A ( $\operatorname{IgA})$ was measured with a slightly modified method of Merino-Guzman et al. (2016) using ELISA Kit (Kamiya Biomedical Company, Japan), and corticosterone (CTC) hormone was measured based on the method of Weimer et al. (2018). Performances including body weight gain (BWG), feed consumption, and feed conversion ratio (FCR) were measured as reported elsewhere (Yuanita et al., 2019). Determination of fecal $\mathrm{N}^{\tau}$-methylhistidine $\left(\mathrm{N}^{\tau}-\mathrm{MH}\right)$ excretion was performed according to the previous report (Suthama et al., 2006). This intermediary product of amino acid breakdown was an indicator of the rate of muscle protein degradation that could be a very important determinant for protein deposition.

\section{Experimental Design and Statistical Analysis}

The present study was arranged in a completely randomized design with three treatments, based on experimental diets tested, and eight replications. Eight birds were kept in the respective replication. Analysis of variance was applied to evaluate the effect of treatments and continued to Duncan multiple range tests at 5\% probability (Steel \& Torrie, 1991).

\section{RESULTS}

\section{Nutrients Digestibility and Retention}

Protein digestibility, retentions of nitrogen and calcium were significantly $(p<0.05)$ higher when given a diet composed of microparticle protein derived from fishmeal and soybean meal that was added with either $1.2 \mathrm{~mL}$ (P2) or $2.4 \mathrm{~mL}$ (P3) lime juice as compared to control (P1) (Table 2). Digestibility of some essential amino acids such as arginine, lysine, and methionine, were significantly improved by both treatments of P2 and P3, except tryptophan and valine were the same for all treatments.

\section{Immune Status and Growth Performance}

The weights of lymphoid organs (bursa fabricius and lymph) were not affected by the treatments. However, $\mathrm{H} / \mathrm{L}$ ratio and fecal $\mathrm{N}^{\tau}-\mathrm{MH}$ excretion were significantly $(p<0.05)$ decreased by feeding diet composed of microparticle protein of fishmeal and soybean meal added with $1.2 \mathrm{~mL}$ (P2) as well as $2.4 \mathrm{~mL}$ (P3) acidifier of lime juice (Table 3 ). Blood IgA concentration and BWG increased due to feeding dietary treatments of P2 and P3, but feed consumption and FCR were significantly $(\mathrm{p}<0.05)$ decreased by both treatments (P2 and P3).

\section{DISCUSSION}

\section{Nutrients Digestibility and Retention}

The increased digestibility of protein and $\mathrm{N}$ retention was closely related with Ca retention as a "combin- 
ing effect" of the use of protein microparticle and organic Ca. Protein utilization efficiency can be improved by processing protein source ingredients become protein with micro in size and added with acidifier of lime juice (Table 2). The improved protein digestibility and $\mathrm{N}$ retention were previously proved in broiler chicken given pelleted microparticle protein derived from either fishmeal or soybean meal (Suthama \& Wibawa, 2018). Protein and especially $\mathrm{Ca}$ be much more absorbed when supported by the conducive intestinal condition. Acidifier of lime juice was able to condition the gastrointestinal tract to be in an acidic state. Since calcium absorption was determined by the absorbed protein and solubility differences (Driver et al., 2005), thus, Ca absorption seemed to depend on the existence of saturable and non-saturable pathways under the regulatory effect of vitamin D status (Fleet \& Schoch, 2010).

Table 2. Protein and amino acid digestibility, nitrogen $(\mathrm{N})$, and calcium $(\mathrm{Ca})$ retentions of broiler chicken

\begin{tabular}{lccc}
\hline \multirow{2}{*}{ Variables } & \multicolumn{3}{c}{ Dietary treatments } \\
\cline { 2 - 4 } & $\mathrm{P} 1$ & $\mathrm{P} 2$ & $\mathrm{P} 3$ \\
\hline Protein digestibility (\%) & $80.6 \pm 8.1^{\mathrm{b}}$ & $83.3 \pm 8.4^{\mathrm{a}}$ & $83.1 \pm 7.8^{\mathrm{a}}$ \\
N retention (\%) & $59.4 \pm 5.0^{\mathrm{b}}$ & $64.2 \pm 6.1^{\mathrm{a}}$ & $63.8 \pm 6.8^{\mathrm{a}}$ \\
Ca retention (\%) & $53.1 \pm 4.6^{\mathrm{b}}$ & $57.9 \pm 5.3^{\mathrm{a}}$ & $56.7 \pm 5.6^{\mathrm{a}}$ \\
Amino acid digestibility & & & \\
$\quad$ Arginine (\%) & $80.9 \pm 7.9^{\mathrm{b}}$ & $84.6 \pm 7.5^{\mathrm{a}}$ & $84.2 \pm 7.8^{\mathrm{a}}$ \\
Isoleucine (\%) & $79.7 \pm 7.5^{\mathrm{b}}$ & $82.9 \pm 8.0^{\mathrm{a}}$ & $80.8 \pm 8.1^{\mathrm{ab}}$ \\
Leucine (\%) & $80.5 \pm 7.7^{\mathrm{b}}$ & $85.8 \pm 8.6^{\mathrm{a}}$ & $83.1 \pm 7.4^{\mathrm{ab}}$ \\
Lysine (\%) & $82.4 \pm 7.1^{\mathrm{b}}$ & $87.1 \pm 7.9^{\mathrm{a}}$ & $86.3 \pm 7.9^{\mathrm{a}}$ \\
Methionine (\%) & $65.5 \pm 6.2^{\mathrm{b}}$ & $70.3 \pm 6.9^{\mathrm{a}}$ & $69.7 \pm 6.4^{\mathrm{a}}$ \\
Phenylalanine (\%) & $81.3 \pm 7.8^{\mathrm{ab}}$ & $83.3 \pm 8.8^{\mathrm{a}}$ & $79.8 \pm 7.1^{\mathrm{b}}$ \\
Tryptophan (\%) & $80.7 \pm 8.3$ & $81.6 \pm 7.8$ & $80.0 \pm 7.3$ \\
Valine (\%) & $77.4 \pm 7.0$ & $79.1 \pm 6.8$ & $78.5 \pm 7.0^{\circ}$ \\
\hline
\end{tabular}

Note: P1= Feed composed of intact fish meal and soybean meal without Ca of egg shell; P2= Feed composed of microparticle protein of fish meal and soybean meal, and Ca of egg shell $+1.2 \%$ acidifier of lime juice; $\mathrm{P} 3=$ Feed composed of microparticle protein of fish meal and soybean meal, and Ca of egg shell $+2.4 \%$ acidifier of lime juice. Means in the same row with different superscripts differ significantly $(\mathrm{p}<0.05)$
The acidic condition of each intestinal segment is different that can affect the rate of Ca utilization. For example, Ca solubility is less than $20 \%$ in ileum due to $\mathrm{pH}$ ranging from neutral to alkaline. In the form of calciumbinding protein $(\mathrm{CaBP})$, both nutrients, protein, and $\mathrm{Ca}$ were possible to be absorbed in a lower $\mathrm{pH}$ condition due to lime juice addition. As a comparison, it was reported that the addition of organic acids to the intact dietary protein improved intestinal morphology (Adil et al., 2010; Nourmohammadi \& Afzali, 2013), decreased $\mathrm{pH}$, increased body resistance, and protein deposition (Jamilah et al., 2013), improved nutrient digestibility and performance of broiler (Ndelekwute et al., 2018) and Pelung chicken (Mangisah et al., 2016). Protein in the form of micro in size (microparticle) and Ca of eggshell can guarantee a higher protein availability and Ca solubility, respectively, and thus, forming a higher number of CaBP that can further be absorbed and utilized to increase production performance of broiler. Although CaBP was not measured in this study, it has been previously stated that $\mathrm{Ca}$ ion has undergone the process of adaptation to the dietary protein under the control of digestive enzymes (Ren et al., 2012).

It has been previously discussed that the increased protein and lysine digestibility due to the feeding effect of the microparticle protein diet added with acidifier of lime juice (Table 2) could be correlated with the higher number of $\mathrm{CaBP}$ in general, and calcium-binding lysine in particular. The higher $\mathrm{Ca}$ binding formation with protein or lysine in the intestinal lumen is an indication of the more protein and Ca that can be absorbed and distributed to the target cell in the body. The increased tibia ash content and the improved body weight gain due to the higher $\mathrm{Ca}$ retention and protein digestibility, respectively, were along with the increasing level of dietary protein and Ca availability (Driver et al., 2005). There was an interactive effect of dietary protein and $\mathrm{Ca}$ levels on $\mathrm{Ca}$ and Nitrogen metabolisms as indicated by the growth of tibia bone (Ziaei et al., 2011). A previous study supported that partially added Ca to the diet containing lower Ca with 19\% protein positively impacted protein digestibility (Wilkinson et al., 2014). Moreover, feed containing microparticle protein and served in pel-

Table 3. Immune status, fecal methylhistidine $\left(\mathrm{N}^{\tau}-\mathrm{MH}\right)$ excretion, and growth performance of broiler chicken

\begin{tabular}{|c|c|c|c|}
\hline \multirow{2}{*}{ Variables } & \multicolumn{3}{|c|}{ Dietary treatments } \\
\hline & P1 & P2 & P3 \\
\hline \multicolumn{4}{|l|}{ Lymphoid organ weight } \\
\hline Bursa fabricius (\%) & $0.21 \pm 0.02$ & $0.31 \pm 0.03$ & $0.27 \pm 0.03$ \\
\hline Lymph $(\%)$ & $0.13 \pm 0.02$ & $0.14 \pm 0.02$ & $0.13 \pm 0.02$ \\
\hline $\mathrm{H} / \mathrm{L}$ ratio & $0.41 \pm 0.05^{\mathrm{a}}$ & $0.33 \pm 0.03^{\mathrm{b}}$ & $0.35 \pm 0.04^{b}$ \\
\hline IgA concentration $(\mu \mathrm{g} / \mathrm{mL})$ & $221.6 \pm 21.1^{\mathrm{b}}$ & $282.8 \pm 24.9^{a}$ & $274.6 \pm 26.8^{a}$ \\
\hline Fecal N${ }^{\tau}-\mathrm{MH}(\mu \mathrm{mol} /$ day $)$ & $10.72 \pm 1.09^{a}$ & $9.06 \pm 0.94^{\mathrm{b}}$ & $9.33 \pm 0.87^{\mathrm{b}}$ \\
\hline Feed consumption (g/bird) & $2,332 \pm 42.7^{a}$ & $2,263 \pm 51.9^{b}$ & $2,266 \pm 42.3^{b}$ \\
\hline Body weight gain (BWG, g/bird) & $1,221 \pm 41.1^{\mathrm{b}}$ & $1,271 \pm 48.7^{a}$ & $1,245 \pm 52.5^{\mathrm{ab}}$ \\
\hline Feed conversion ration (FCR) & $1.91 \pm 0.20^{\mathrm{a}}$ & $1.78 \pm 0.17^{\mathrm{b}}$ & $1.82 \pm 0.17 \mathrm{~b}$ \\
\hline
\end{tabular}

Note: P1= Feed composed of intact fish meal and soybean meal without Ca of egg shell; P2= Feed composed of microparticle protein of fish meal and soybean meal, and Ca of egg shell $+1.2 \%$ acidifier of lime juice; P3= Feed composed of microparticle protein of fish meal and soybean meal, and Ca of egg shell $+2.4 \%$ acidifier of lime juice. Means in the same row with different superscripts differ significantly $(\mathrm{p}<0.05)$. 
let form was found to be more advantageous for broiler (Saputra et al., 2020), but still questionable for the layer.

The experiment concerning the combination of protein sources of microparticle and organic $\mathrm{Ca}$ added with lime juice as acidifier has never been conducted, but micro in size is believed to have beneficial and advantageous effects. The size of feed particles, in general, has been reported to have many advantages in relation to some aspects of poultry products, such as the development of gastrointestinal tract, nutrition utilization, and performance (Amerah et al., 2008; Pacheco et al., 2013; Rubio et al., 2020). Reducing particle size was closely related to the accessibility of digestive enzymes on the feed components and resulted in the improvement of nutrients digestibility (Jambrak et al., 2014; Huang \& Stein, 2016). The increased protein digestibility and some essential amino acids due to feeding microparticle protein and $\mathrm{Ca}$ organic-composed diet with the addition of lime juice could provide the evidence.

\section{Immune Status and Growth Performance}

The increased protein digestibility, $\mathrm{N}$ and Ca retentions found in the present study (Table 2), which principally supported BWG, cannot be separated from the condition of intestinal health. The healthy intestinal tract indicated by the higher lactic acid bacteria population and the low coliform counts brought about better villi growth. This intestinal ecology improved protein digestibility and higher BWG in up-graded local chicken fed a combination of inulin and Lactobacillus sp. (Purbarani et al., 2019). Similarly, feed with the inclusion of inulin and Lactobacillus sp. given to crossbred local chicken improved performance (Abdurrahman et al., 2016a) and meat characteristics (Abdurrahman et al., 2016b). The better production performance of birds fed either P2 or P3 dietary treatments was closely related to the improved gut health and was also supported by higher body resistance with a lower $\mathrm{H} / \mathrm{L}$ ratio, although bursa fabricius was not significantly affected (Table 3 ). It is comparable with the previous results that the weight of bursa fabricius increased and $\mathrm{H} / \mathrm{L}$ ratio decreased in the crossbred local chicken fed additive extract of inulin dahlia tuber (Fajrih et al., 2014), and in broiler given glucomannan of porang tuber (Perdinan et al., 2019). Results of the present study indicated the same phenomenon that broilers given feed composed of microparticle protein and Ca sources added with lime juice decreased $\mathrm{H} / \mathrm{L}$ ratio as an index of health status. The decreased value of $\mathrm{H} / \mathrm{L}$ ratio was supported by the stronger factor as a determinant of the immune system, namely, immunoglobulin A (Table 3). The improvement of the immune system of broiler chicken was proved by the increased blood circulation of IgA in P2 as well as in P3 treatments. The healthier the birds, the more efficient in the use of nutrients or feed that can be proved by the reduced feed consumption and thus lowered FCR.

Fecal $\mathrm{N}^{\tau}-\mathrm{MH}$ excretion significantly $(\mathrm{p}<0.05)$ lower, but blood circulation of IgA significantly $(p<0.05)$ higher in either P2 or P3 compared to that in P1 (Table 3). This condition is very helpful for nutritional metabolism that can boost broiler growth that eventually produced a better growth of bone and muscle. Supplementation of acidifier of lime juice to the feed composed of microparticle protein and Ca organic sources positively impacts the modification of intestinal tract and thus nutrients absorption, such as protein, $\mathrm{Ca}$, and amino acids (Table 2). The increased nutrients utilization due to the improved health status or immune system with higher IgA concentration and lower $\mathrm{H} / \mathrm{L}$ ratio was beneficial for boosting BWG, although the weight of lymphoid organs was the same (Table 3). Also, the reduced fecal $\mathrm{N}^{\tau}-\mathrm{MH}$ excretion can be an indication of higher efficiency of protein/amino acids utilization and this phenomenon was consistent with the report of Suthama (2006). The decreased fecal $\mathrm{N}^{\tau}-\mathrm{MH}$ excretion can be correlated with the improved amino acids digestibility such as arginine until phenylalanine in P2, but only arginine, lysine, and methionine significantly increased in P3 (Table 2). The present study was consistent with the result of Goh et al. (2020), who reported that dietary inclusion of the mixture of organic acid-palm fat improved nutrient digestibility and had a beneficial effect on the growth performances of broiler chicken. An interesting result found in this research that BWG was not affected by the reduced feed consumption (Table 3) because it was covered by the increased protein and amino acid digestibility (Table 2). This result was in accordance with the previous study (Ndelekwute \& Enyenihi, 2017) that broiler fed intact protein diet with the inclusion of lime juice at $1.5 \%$ increased protein digestibility, and that with the level at $2 \%$ improved live body weight.

It has been previously described that the improvement of protein and/or amino acids efficiency was proved by the decreased fecal $\mathrm{N}^{\tau}-\mathrm{MH}$ excretion as an index of the rate of body protein degradation, which boils down to the increased BWG. Similar results were previously reported that broiler fed ration containing microparticle protein added with Lactobacillus sp. indicated a low coliform population as a secondary indicator, so that resulted in a higher BW (Cholis et al., 2018). The improvement of BWG was due to the reduced fecal $\mathrm{N}^{\tau}-\mathrm{MH}$ excretion as an index of protein turnover in Kedu chicken fed ration containing intact protein sources (Suthama, 2006), and caused by the decreased $\mathrm{H} / \mathrm{L}$ ratio in broiler given acidifier (Jamilah et al., 2013). It can be briefly summarized that broiler fed a ration with microparticle protein and source of organic Ca added with lime juice as acidifier enhanced immune status and improved production performances.

\section{CONCLUSION}

Feed composed of microparticle protein and Ca organic sources with the inclusion of lime juice as acidifier at both levels $(1.2 \mathrm{~mL}$ and $2.4 \mathrm{~mL})$ improve broiler performance. Acidifier of lime juice at the lower level $(1.2 \mathrm{~mL})$ is considered more economical based on the reduced feed consumption and the increased protein and amino acids digestibility, immunoglobulin A concentration, and body weight gain. 


\section{CONFLICT OF INTEREST}

The authors declare that there is no any conflict of interest with other organizations concerning either financial support or experimental material used in the manuscript.

\section{REFERENCES}

Abdelrazek, H. M. A., S. M. M. Abuzead, S. A. Ali, H. M. A. El-Genaidy, \& S. A. Abdel-Hafez. 2016. Effect of citric and acetic acid water acidification on broiler's performance with respect to thyroid hormones levels. Adv. Anim. Vet. Sci. 4:271-278. https://doi.org/10.14737/journal. aavs/2016/4.5.271.278

Abdurrahman, Z. H., Y. B. Pramono, \& N. Suthama. 2016a. Feeding effect of inulin derived from dahlia tuber combined with Lactobacillus sp. on meat protein mass of crossbred kampong chicken. J. Indones. Trop. Anim. Agric. 41:37-44. https://doi.org/10.14710/jitaa.41.1.37-44

Abdurrahman, Z. H., Y. B. Pramono, \& N. Suthama. 2016b. Meat characteristic of crossbred local chicken fed inulin of dahlia tuber and Lactobacillus sp. Med. Pet. 39:112-118. https://doi.org/10.5398/medpet.2016.39.2.112

Adil, S., T. Banday, G. A. Bhat, M. S. Mir, \& M. Rehman. 2010. Effect of dietary supplementation of organic acids on performance, intestinal histomorphology, and serum biochemistry of broiler chicken. Vet. Med. Int. 20:1-7. https:// doi.org/10.4061/2010/479485

Al-Jaf, K. A. H. \& Y. K. Del. 2019. Effect of different feed additives on growth performance and production in livestock. Int. J. Agric. For. 9:16-31.

Amerah, A. M., V. Ravindran, R. G. Lentle, \& D. G. Thomas. 2008. Influence of feed particle size on the performance, energy utilization, digestive tract development, and digesta parameters of broiler fed wheat- and corn-based diets. Poult. Sci. 87:2320-2328. https://doi.org/10.3382/ ps.2008-00149

Castanon, J. I. R. 2007. History of the use of antibiotic as growth promoters in European poultry feeds. Poult. Sci. 86:24662471. https://doi.org/10.3382/ps.2007-00249

Cholis, M.A., N. Suthama, \& B. Sukamto. 2018. Feeding microparticle protein diet combined with Lactobacillus sp. on existence of intestinal bacteria and growth of broiler chickens. J. Indones. Trop. Anim. Agric. 43:265-271. https://doi. org/10.14710/jitaa.43.3.265-271

Dhama, K., R. Tiwari, R. U. Khan, S. Chakraborty, M. Gopi, K. Khartik, M. Saminathan, P. A. Desingu, \& L. T. Sunkara. 2014. Growth promoter and novel feed additives improving poultry production and health, bioactives principles and beneficial applications: The trends and advances - A review. Int. J. Pharmacol. 13:129-159. https://doi. org/10.3923/ijp.2014.129.159

Driver, J. P., G. M. Pesti, R. I. Bakalli, \& H. M. Edwards, Jr. 2005. Calcium requirements of the modern broiler chicken as influenced by dietary protein and age. Poult. Sci. 84:1629-1639. https://doi.org/10.1093/ps/84.10.1629

Fajrih, N., N. Suthama, \& V. D. Yunianto. 2014. Body resistance and productive performances of crossbred local chicken fed inulin of dahlia tubers. Med. Pet. 37: 108-114. https:// doi.org/10.5398/medpet.2014.37.2.108

Fleet, J. M. \& R. D. Schoch. 2010. Molecular mechanisms for regulation of intestinal Calcium absorption by vitamin D and other factors. Crit. Rev. Clin. Lab. Sci. 47:181-195. https://doi.org/10.3109/10408363.2010.536429

Goh, C. H., T. C. Loh, H. L. Foo, \& F. Nobilly. 2020. Fecal microbial population and growth in broiler fed organic acids and palm fat-composed diet. Trop. Anim. Sci. J. 43:151-157. https://doi.org/10.5398/tasj.2020.43.2.151

Hayajneh, F. M. F. 2019. Natural feed additives for broiler chickens. S. Afr. J. Anim. Sci. 49:867-873. https://doi.org/10.4314/ sajas.v49i5.9

Huang, C. \& H. H. Stein. 2016. Amino acid digestibility in soy protein concentrate with different particle sizes fed to weanling pigs. Pig Progress Res. Report. p. 32-33.

Jambrak, A. R., T. J. Mason, V. Lelas, L. Paniwnyk, \& Z. Herceg. 2014. Effect of ultrasound treatment on particle size and molecular weight of whey proteins. J. Food Eng. 121:15-23. https://doi.org/10.1016/j.jfoodeng.2013.08.012

Jamilah, N. Suthama, \& L. D. Mahfudz. 2013. Performa produksi dan ketahanan tubuh broiler yang diberi pakan step down dengan penambahan asam sitrat sebagai acidifier. Jurnal Ilmu Ternak dan Veteriner. 18:251-257. (In Indonesian language with English abstract).

Krismiyanto, L., N. Suthama, \& H. I. Wahyuni. 2014. Feeding effect of inulin derived from Dahlia variabilis tuber on intestinal microbes in starter period of crossbred native chickens. J. Indones. Trop. Anim. Agric. 39:217-223. https:// doi.org/10.14710/jitaa.39.4.217-223

Landers, T. F., B. Cohen, T. E. Wittum, \& E. L. Larson. 2012. A review of antibiotic use in food animals: Perspective, policy, and potential. Public Health Rep. 127:4- 22. https:// doi.org/10.1177/003335491212700103

Mangisah, I., B. Sukamto, H. I. Wahyuni, I. Estiningdriati, W. Saputro, \& L. Krismiyanto. 2016. Nutrient digestibility and performance of male pelung chicken fed rice based ration supplemented with lime (Citrus aurantifolia) juice. Med. Pet. 39:119-124. https://doi.org/10.5398/ medpet.2016.39.2.119

Mehdi, Y., M.-P. Letourneau-Montminy, M.-L. Gaucher, Y. Chorfi, G. Suresh, T. Rouissi, S. K. Brar, C. Cot , A. A. Ramirez, \& S. Godbout. 2018. Use of antibiotics in broiler production: Global impacts and alternatives. Anim. Nutr. 4:170-178. https://doi.org/10.1016/j.aninu.2018.03.002

Merino-Guzman, R. , J. D. Latorre, R. Delgado, X. HernandezVelasco, A. D. Wolfenden, K. D. Teague, L. E. Graham, B. D. Mahaffey, M. F. A. Baxter, B. M. Hargis, \& G. Tellez. 2016. Comparison of total immunoglobulin A levels in different samples in Leghorn and broiler chickens. Asian Pac. J. Trop. Biomed. 7:116-120. https://doi.org/10.1016/j. apjtb.2016.11.021

Ndelekwute, E. K. \& G. E. Enyenihi. 2017. Lime juice as a source of organic acids for growth and apparent nutrient digestibility of broiler chickens. J. Vet. Med. Surgery 1:1-5.

Ndelekwute, E. K., E. D. Assam, \& E. M. Assam. 2018. Apparent nutrient digestibility, gut $\mathrm{pH}$ and digesta viscosity of broiler chickens fed acidified water. MOJ Anat. Physiol. 5:250253. https://doi.org/10.15406/mojap.2018.05.00203

Nourmohammadi, R. \& N. Afzali. 2013. Effect of citric acid and microbial phytase on small intestinal morphology in broiler chicken. Ital. J. Anim. Sci. 12:44-47. https://doi. org/10.4081/ijas.2013.e7

Pacheco, W. J., C. R. Stark, P. R. Ferket, \& J. Brake. 2013. Evaluation of soybean meal source and particle size on broiler performance, nutrient digestibility, and gizzard development. Poult. Sci. 92:2914-2922. https://doi. org/10.3382/ps.2013-03186

Pan, D. \& Z. Yu. 2014. Intestinal microbiome of poultry and its interaction with host and diet. Gut Microbes. 5:108-119. https://doi.org/10.4161/gmic.26945

Perdinan, A., H. I. Wahyuni, \& N. Suthama. 2019. Body resistance and growth performance of broiler fed glucomannan extracted from Amorphophallus onchophyllus Tuber. Trop. Anim. Sci. J. 42:33-38. https://doi.org/10.5398/ tasj.2019.42.1.33

Purbarani, S. A., H. I. Wahyuni, \& N. Suthama. 2019. Dahlia Inulin and Lactobacillus sp. in step down protein diet on villi 
development and growth of KUB chickens. Trop. Anim. Sci. J. 42:19-24. https://doi.org/10.5398/tasj.2019.42.1.19

Ravindran, V., L. I. Hew, G. Ravindran, \& W. L. Bryden. 1999. A comparison of ileal digesta and excreta analysis for the determination of amino acid digestibility in food ingredients for poultry. Br. Poult. Sci. 40:266-274. https://doi. org/10.1080/00071669987692

Ren, L O., F. Zhao, H. Z. Tan, J. T. Zhao, J. Z. Zhang, \& H. F. Zhang. 2012. Effects of dietary protein source on the digestive enzyme activities and electrolyte composition in the small intestinal fluid of chickens. Poult. Sci. 91:1641-1646. https://doi.org/10.3382/ps.2011-02081

Risdianto, D., N. Suthama, E. Suprijatna, \& S. Sunarso. 2019. Inclusion effect of ginger and turmeric mixture combined with Lactobacillus spp. isolated from rumen fluid of cattle on health status and growth of broiler. J. Indones. Trop. Anim. Agric. 44:423-433. https://doi.org/10.14710/ jitaa.44.4.423-433

Rubio, A. A., J. B. Hess, W. D. Berry, W. A. Dozier III, \& W. J. Pacheco. 2020. Effets of corn particle size on broiler performance during the starter, grower, and finisher periods. J. Appl. Poult. Res. 29:352-361. https://doi.org/10.1016/j. japr.2019.11.009

Salim, H. M. D., K. S. Huque, K. M. Kamaruddin, \& M. D. A. H. Beg. 2018. Global restriction of using antibiotic growth promoters and alternative strategies in poultry production. Sci. Prog. 101:52-75. https://doi.org/10.3184/00368501 8X15173975498947

Saputra, Y. A., N. Suthama, \& B. Sukamto. 2020. Feeding diets composed of low level microparticle protein derived from fish and soybean meals and using organic calcium added with Lactobacillus acidophilus or citric acid on intestinal condition and performance of broilers. Livest. Res. Rural. Dev. 32:37-53.

Sibbald, I. R. \& S. Wolynetz. 1985. Estimates of retained nitrogen used to correct estimates of bioavailable energy. Poult. Sci. 64:1506-1513. https://doi.org/10.3382/ps.0641506
Sivaraman, S. \& V. Parady. 2018. Antibiotic Use in Food Animals: Indonesia Overview. ReAct Asia-Pacific Christian Medical College, Vellore, Tamil Nadu. Section C, p. 28.

Steel, R. G. D. \& J. H. Torrie. 1991. Principles and Procedures of Statistics: A Biometrical Approach. McGraw-Hill Book Company, New York, Toronto, London

Suthama, N. 2006. Kajian aspek "protein turnover" tubuh pada ayam Kedu periode pertumbuhan. Med. Pet. 29:47-53. (In Indonesian language with English abstract).

Suthama, N. \& P.J. Wibawa. 2018. Amino acids digestibility of pelleted micro-particle protein of fish meal and soybean meal in broiler chickens. J. Indones. Trop. Anim. Agric. 43:169-176. https://doi.org/10.14710/jitaa.43.2.169-176

Weimer, S. L, R. F. Wideman, C. G. Scanes, A. Mauromoustakos, K. D. Christensen, \& Y. Vizzier-Thaxton. 2018. An evaluation of methods for measuring stress in broiler chickens. Poult. Sci. 97:3381-3389. https://doi.org/10.3382/ps/pey204

Wilkinson, S. J., P. H. Selle, M. R. Bedford, \& A. J. Cowieson. 2013. Separate feeding of calcium improves performance and ileal nutrient digestibility in broiler chicks. Anim. Prod. Sci. CSIRO. Pub. p. A - G. https://doi.org/10.1071/ AN12432

Yang, Y., P.A. Iji, \& M. Choct. 2009. Dietary modulation of gut microflora in broiler chickens: A review of the role of six kinds of alternatives to in-feed antibiotics. World's Poult. Sci. J. 65:97-114. https://doi.org/10.1017/S0043933909000087

Yuanita, I., D. Sunarti, H. I. Wahyuni, \& N. Suthama. 2019. Feeding Dayak onion (Eleutherine palmifolia) extract and Lactobacillus acidophilus mixture on blood biochemicals, meat quality characteristics and growth performance in broiler chickens. Livest. Res. Rural. Dev. 31:16-22.

Ziaei, N., H. Kermanshahi, \& M. PileVar. 2011. Effects of dietary crude protein and calcium/phosphorus content on growth, nitrogen and mineral retention in broiler chickens. Afr. J. Biotechnol. 10:13342-13350. 